\title{
Capital Structure in Emerging Markets: Evidence from China
}

\author{
Varvara Nazarova \\ $\mathrm{PhD}$ in Economics, Researcher, Associate Professor \\ $\underline{\text { ORCID }}$ \\ E-mail: nvarvara@list.ru
}

National Research University Higher School of Economics, Russia

Soyuza Pechatnikov St, 16, 190008 Saint Petersburg, Russia

\section{Anastasia Budchenko}

Specialist

$\underline{\text { ORCID }}$

E-mail: budchenko.as@yandex.ru

“LEROY MERLIN”, Moscow, Russia

Journal of Corporate Finance Research, Vol. 14, No. 1, pp. 7-19 (2020)

DOI: https:// 10.17323/j.jcfr.2073-0438.14.1.2020.7-19

Received 4 February 2020 | Peer-reviewed 10 March 2020 | Accepted 13 March 2020

The journal is an open access journal which means that everybody can read, download, copy, distribute, print, search, or link to the full texts of these articles in accordance with CC Licence type: Attribution 4.0 International (CC BY 4.0 http://creativecommons.org/licenses/by/4.0/). 


\section{Capital Structure in Emerging Markets: Evidence from China}

\section{Abstract}

Although corporate capital structure has been intriguing to scientists for a number of years, very little research has been conducted on the topic for companies in emerging markets. The purpose of this paper is to investigate the determinants of capital structure using a sample of 195 non-financial firms from emerging markets in 2012-2016.

The inclusion of a specific dataset from Chinese companies lends vital focus to this investigation and provides crucial ballast for the investigative function. The final sample contains data on 57 China companies and 90 other companies of emerging markets. Our article focusses on identifying the determinants of capital structure of Chinese companies in comparison with companies of other BRIC countries (Brazil, Russia, India), and sets out a series of hypotheses concerning capital structure with domestic and international variables. We compare and contrast our data using a series of custom evaluation models based on linear regressions.

The results confirm positive impact of tangibility on total debt ratio due to a high share of capital-intensive industries in the sample. It is revealed that growth rates and firm size have positive impacts on financial leverage in Chinese companies as compared to other BRIC countries, and these effects are stronger in capital-intensive industries. We illustrate how a strong negative impact of ROA has increased in recent years, and connect this phenomenon to a considerable decrease in lending rates following a large-scale stimulus program which encouraged Chinese companies to borrow money instead of relying on retained earnings. The presence of the Chinese state in the ownership structure of companies is revealed to be significant for the majority of Chinese companies, especially for the oil and gas and metallurgical sectors.

Our conclusions highlight the importance of government policies and special market conditions in explaining the financing behaviour of companies in emerging countries like China. While capital structure choice varies significantly across industries, nevertheless the differences between Chinese and other BRIC companies reflect the differences in the institutional structure of financing mechanisms in countries. This research and evaluation is especially timely considering the increased focus on Chinese commercial exposure on the world stage, a tendency which is bound to increase research interest in the near future across a range of disciplines. As such, our study and our broad range of conclusions will prove invaluable for students, researchers, policymakers, and decision makers in business, commerce, politics and academia at all levels.

Key words: Chinese companies, capital structure, emerging markets, debt ratio, BRIC companies, financial leverage, financing policies, emerging capital markets

JEL classification: F21; F38; E22; G31; G32 


\section{Introduction}

Capital structure decisions are an essential part of any business. Firms are regularly faced with controversial issues connected to financing their activities. in general, financing resources may be divided into two categories - debt and equity. Both groups resources are vital for business, and the capital structure is represented as a dynamic combination of both. The equity to debt ratio influences the company value and the willingness of creditors to lend money for the business. It is believed that there is a particular proportion of the debt and equity combination that allows for maximising the firm value and for minimising the weighted average cost of capital. Many studies have been devoted to discovering this proportion. All the existing theories have their supporters and opponents, and as the results vary from one research to the next, empirical studies still cannot provide a reliable prescription for optimal capital structure. Discrepancies may be attributable to the usage of different methodologies. This situation is equally uncertain for both developed and developing countries, but in the case of emerging economies this is especially important as their markets are very young and sensitive, which makes them quite unstable. A clear solution to the capital structure problem could give companies in these markets a solid base for sustainable development, and will substantially contribute to stabilising their markets as a whole.

The research problem for this paper is that nowadays there is no clear answer to the question of what the optimal capital structure for firms in a developing economy should be. Responding to the needs of this problem, the goal of this research will be to study how different firm characteristics associated with capital structure influence firm growth in emerging markets. This will help to identify methods to bring the capital structure closer to the optimal level and to form some recommendations about maximisation of the firm's chances for successful development through rearrangement of the capital structure. This knowledge can also be a guide for such firms to prevent against possible dangerous mistakes in hindering sustainable growth when making capital structure decisions. As previously mentioned, this could be immensely important in the conditions of developing markets, which usually lack stability. As such, solving the research problem will have significant managerial importance and clear future implications for firms.

According to a number of studies, emerging capital markets have grown substantially over the past decades, most notably so during the 1990s. Among the numerous governmental initiatives aimed at facilitating this process, the liberalisation of the financial sector is perhaps the most important. It normally includes such stages as stock market liberalisation, weakening the grip on interest rates, lowering the number of programs of directed credit, etc., in order to make the financial sector more efficient, provide the market with more freedom, facilitate the use of securities, and introduce more options for cross-border risk diversification. In turn, technological advances contribute to this process through lower transaction costs and an overall simplification of operations, leading to increased efficiency. Foreign investors start buying securities to diversify their portfolios. Moreover, such financial tools as illiquid asset securitisation are also a major factor in emerging market development.

However, there are a number of aspects that hinder market development and stand in the way of incoming capital resources. Companies that operate in developing economies are influenced by the following conditions:

- Limited access to capital resources

- Considerable information asymmetry and agency costs

- Great macroeconomic risks resulting from the instability of the system and constant changes

- Poor corporate management

Any of these distinctions may have a considerable impact in a given situation; however, the most important issue here is the extent of their influence on the big picture.

Limited access to capital resources may prevent a company from benefitting from certain types of financing that could potentially improve its capital structure and lead to long-term growth.

Asymmetric information also may lead to significant consequences for investors (both local and from other countries), companies, and governments. According to Sara Xiaoya Ding [1], it may have critical effects on the result of certain investment decisions. While emerging markets offer a wide variety of investment options, information asymmetry makes them extremely difficult to assess, which means that a lot of potential investors choose not to deal with developing economies.

The general instability of both emerging economies and macroeconomic risks also has a detrimental influence on the capital market: potential creditors and investors are put off by high inflation rates, which means that they cannot be certain about making financial decisions when it comes to developing markets [2]. A number of studies claim that a volatile economy may result in fewer financing options for companies, which takes us back to the aforementioned issue of access to capital resources.

Heavily concentrated ownership and ineffective corporate governance are also typical of emerging markets. The biggest companies are often family- or state-owned. According to Rajagopal [3], compared to developed European countries or the USA, Thailand is marked by extremely concentrated ownership. This, in turn, leads to ineffective corporate management, as managerial positions are often given to one's friends or relatives, who may lack the necessary qualifications [4]. These problems may stand in the way of attracting foreign investment, which in turn may hinder market development.

To summarise, when it comes to developing economies, economic development and capital structure are influenced by the markets' unique characteristics in both positive and negative ways. 
Nevertheless, while emerging markets may have their problems, they have undoubtedly become a vital part of the global economy. According to the data of European Central Bank (n.d.), $80 \%$ of people live in developing economies. Their output is now more than $30 \%$ of the global total, and World Economic Outlook states that this figure is only going to grow. This is good news for everybody, as it gives new opportunities to developed economies and has the potential to bring stability to the global economy.

A plurality of experts agree with the fact that the Chinese market is extremely attractive and has a lot of potential, and the charts above make it clear that China is in the lead across the board. Its GDP was growing at the average rate of $9 \%$ from 1979 to 2007, and, together with considerable economic and social changes, it swiftly brought the country to the economic level that other countries needed decades or even centuries to achieve. China's expenditure, speedy progress, efficient use of numerous state-of-the-art technologies and optimal financial innovations all contributed to the growing attention from foreign investors. In this study, we will look at the capital structure of companies in BRIC countries, but the emphasis will be on the results of companies in the Chinese market. This is due to the dominant role of the Chinese market, its development prospects, and the ability to apply the benefits of the experience in the Chinese market to other companies in developing countries.

Emerging markets are a crucial part of the global economy today, and they are likely to have even more influence in the years to come. Every one of them, however, has its own growth rate defined by a given country's political, social and economic circumstances. China is currently in the lead, with competition from India, Brazil, Russia, South Africa and Korea.

As previously mentioned, the greatest contribution to the evolution of attitudes in the formation of capital structure was made by foreign scientists. However, the findings of their work focused more on the analysis of companies operating in developed markets, the terms of which differ significantly from markets of developing countries.

Today there are many lists of emerging markets that were compiled by leading companies in the financial services market. They are, for example, S\&P, MSCI, FTSE Group, Dow Jones \& Company. However, all the lists are consistent in asserting the fact that countries such as Brazil, India, Russia and China are the most significant countries with developing capital markets. These are referred to as the 'BRIC' group of countries (the first letters of the names of the countries).

The debt level of emerging economies is coming closer to that of developed countries. However, conclusions made for the latter do not apply to capital structure issues in emerging markets, as we cannot say with certainty that companies in both markets use the same strategies when deciding upon capital structure. According to a number of researchers, capital structure is considerably influenced by country-specific laws and regulations, corporate tax rates and taxation systems for individuals, and corporate governance, which means that each emerging economy should be studied separately. In order to understand the situation with Chinese companies, we need to study the Chinese economy, which is now the second largest in the world (with the US in the lead), as an independent case. The maturity of the Chinese market makes a case for exploring the capital structure determinants of Chinese companies.

The subject of the research is the capital structure of large companies in developing countries. The data sample includes information for companies operating for the period 2012 to 2016. This time period was selected as it avoids distortion associated with features of the economic situation and economic policy in a particular year. For example, the considered period includes the global financial crisis, which had significant negative impact on the living standards of the general population, as well as the period preceding the global economic crisis and post-crisis period.

The research goal is to investigate the determinants of capital structure using a cross-section sample of companies listed on stock exchanges in the period of 2012-2016.

The research question to be investigated is: What determines the capital structure in the big companies of emerging markets? In essence this is a test of the applicability of some of the findings in earlier studies in other countries.

In order to find an answer to the question above, we need to develop a suitable research design, which would support our objectives, determine information sources and establish analytical principles to be used with the data collected.

At the first level of research design, we apply a deductive approach (as opposed to an inductive one). This involves data collection to help identify a given phenomenon or to create a theory, and begins with proposing a hypothesis based on prior research (in our case, studies on capital structure in developed economies). This is then tested by the gathering of data, the determination of relationships and the provision of relevant reasoning. We also employ the quantitative method because most of the information is obtained from BRIC firms' annual statements. This data is used to test our hypothesis, which is a common practice when the deductive approach and the qualitative method are used together.

At the level of research strategy, our chosen format is that of an experiment intended to keep track of how independent variables change, wherein we will note the effect such changes have on the dependent ones - in other words, it shall help us determine if there is a significant relationship between them. Obtaining information from annual reports also means that our study focusses on historical data.

As for data collection, we use both primary and secondary sources. While our literature overview focusses on prior research of capital structure and other relevant materials 
published in books and journals, the empirical part is based on information obtained from financial reports and annual statements released from 2012 to 2016 .

To summarise, in this article we employ a quantitative research design involving a combination of quantitative analysis and the deductive approach, which are used in the format of an experiment. Our research objective is explained with the use of historical data, which has to be processed and turned into analytical data. This, in turn, defines our objectives for the next year: we need to develop a data analysis methodology, explain variable measurement, and work on model estimation.

\section{Literature review}

The aim of this review is to systematise the main findings which appeared in the literature on capital structure. This involves an analysis of theories of capital structure based on their division into static and dynamic theories. First, we considered the static theory of capital structure, the traditionalist approach of D. Durand, the fundamental theory of F. Modigliani and M. Miller, the trade-off theory and the theory of hierarchy. In the second part we discuss the dynamic models, which can be divided into two types: signalling and compromise. The signal model appeared first, but in recent years it has actively aided in the development of the concept of dynamic trade-off capital structure. We will present the theories in chronological order of their publication, which allows to allocate the basic stages of development of the theory of capital structure, and identify how this theory was supplemented by new factors and conditions. Further, this literature review will outline the basic assumptions and postulates of the theories and their benefits.

In general, the capital structure is usually defined as the ratio of owned and borrowed capital of the company as it corresponds to its long-term development strategy. There are disputes among researchers about what to include in the composition of equity and debt when calculating these indicators. Equity usually includes the company's shares (ordinary and preferred) [5], and sometimes includes retained earnings [6].

With regard to borrowed funds in the composition of capital structure, some authors attribute them to part of the long-term debt of the company [7]; [8]. However, accounting only for long-term borrowings may not reflect the entire debt capital, as some companies can be partly financed by short-term debt. Therefore, several studies into the calculation of the capital structure suggest that short-term debt (excluding accounts payable) should be considered a permanent component thereof [6].

From the definitions given by many previous researchers, capital structure can be referred to as "the combination of sources of funds a firm uses". Maintaining an appropriate capital structure is a critical consideration for any business organisation. According to Simerly and Li [9] the decision is important not only because of the need to maximise returns to the shareholders, but it is also important because of the impact of such decisions on an organisation's ability to deal with its competitive environment.

Previous research suggests that empirical studies of capital structure determinants mainly focus on the US and other developed economies, while the topic is clearly under-researched when it comes to developing countries. A recent example of the latter studies is the work by Booth [10], where the author attempts to find factors influencing capital structure in developing countries by analysing a sample of 10 developing countries. Booth concludes that factors that are relevant for developed countries apply to developing ones as well, regardless of institutional differences. Bhaduri's empirical study on corporate borrowing [11] focusses on the Indian market. The author claims that the optimal capital structure is normally chosen with such factors in mind as earnings growth, a company's size and cash flow, as well as product and industry features.

Kumar's paper [12] focusses on the capital theory and offers an overview of prior research. The article covers the period from 1972 to 2013, and the author is the first to attempt to identify 'blind spots' in the research of capital structure determinants, making suggestions for further investigations. The paper also includes a statistical summary of the results of the existing empirical research on the topic.

There are several reasons why the topic of capital structure in developing economies has grown in popularity. First, the rate of capital borrowing has the potential to greatly influence a company's profitability [13]. Second, it has been determined that decisions concerning corporate financing depend on a large number of policy-related issues [14], which affect security prices and interest rates, the development of the capital market, corporate government development, firm development, profitability, and the stability of exchange rates and inflation.

The diversity of empirical research into the capital structure of companies in developing countries is well-represented by the breadth of studies devoted to the analysis of the determinants and empirical testing of theories of structure formation of capital (the theory of financing order, trade-off theory, theory of market timing, agency, signalling). Mitton [15] made a research of long-term trends of capital structure on the data of 34 emerging markets. The author showed that a significant increase in the debt burden in the period 1980-2004 in emerging capital markets can be explained to a large extent by corresponding changes in the fundamental determinants of companies (the size of the capital of the company, the profitability of total capital, growth opportunities, and asset structure of the company). The significance of the traditional determinants was identified by [13] and [16] by analysing a sample of companies from Malaysia and Hungary respectively. However, the traditional list of determining factors influencing capital structure in developing countries is not limited. Booth and co-authors [10] revealed the importance of macroeconomic factors influencing the ratio of owned and borrowed capital. 
Regarding BRIC countries, the study cited at [17] focussed on a comparative analysis of static trade-off theory and the theory of financing order. The study on the sample of companies from BRIC countries showed that the most significant factors affecting the capital structure are traditional determinants of developed countries, such as the structure of assets of the company, the amount of capital, and the return on capital of the company. The result of the study was that the determinants of capital structure in BRIC countries had no country differences. However, the motives for the formation of capital structure in these countries differ.

The process of testing of the existing concepts of capital structure formation in emerging capital markets is represented by comparatively fewer works.

For example, a study aimed at the empirical testing of the theory of financing order in emerging markets came to the following results. Ivashkovskaya and Makarov [18] used data from European countries to show that the order theory of financing can explain a significant share of new borrowing on the markets of Central and Eastern Europe (CEE), with the sample of determinants identified by the authors speaking in favour of the importance of static trade-off theory. Tong and Green [19], in their study on a sample of the 50 largest companies of China for the period 2001-2003 showed that the behaviour of Chinese companies with respect to the choice of capital structure is largely consistent with the theory of financing order.

The papers of Alani and Alamri [20], Acaravci [21], Rahim [22], and Haron [23] provide reviews of the different views on the present situation in developed and emerging markets and common issues that arise in the previous research of different authors.

It has been established that a company's decision is based not only on the assessment of tax shield benefits and bankruptcy costs, but also on a comparison of the agency costs of equity with those of debt. The cost and benefit analysis for different capital structure plans may include many other factors, but the most important aspect here is that firms come up with an optimal capital structure and then, if it has not yet been reached, they make adjustments. There are a number of studies that confirm that companies make adjustments to reach target debt ratios, for instance, Acaravci [21], Rahim [22], and Haron [23].

Rahim and Saad [22] explore the relationship between sustainable growth, capital structure, and company performance in emerging markets, namely in Thailand, Malaysia, Singapore, and Indonesia. The authors analyse the data from each country over a certain period, and then compare the results. According to this study, most of the parameters are pretty much the same in each country; however, some indicators are significantly different. The divergent group includes ROA (return on assets) and EPS (earnings per share), which usually means that such markets require different conditions for optimal capital structure. Overall, this article has helped us to fine-tune the methodology of our study.
To summarise, all the materials we have analysed offer useful information that can help conduct further research. The works by Fama and French [24], Kemsley and Nissima [25], and Baker and Vurgler [26] have proven to be of value for the theoretical section of our study and have helped us to understand the diversity of capital structure theories. The works by Alani and Alamri [20], Acaravci [21], and Haron [23] present various perspectives of developed and emerging markets today and discuss issues found in previous studies. Studies that examine companies operating in different developing economies are particularly valuable for our purposes, as they can help to identify the features of emerging economies that should be examined more carefully. We discuss some of these features in the next two sections of this article.

Vo [27] contributes further details to the discussion of whether developing markets have different capital structure determinants by analysing a unique data set, which contains company-specific attributes for Vietnamese firms over the period from 2006 to 2015. With a GMM estimator used to control for endogeneity, Vo's findings show that there are different capital structure determinants for long-term and short-term indicators.

Finally, the most recent work devoted to testing the dynamic trade-off concept is the study by Clark and co-authors [28] conducted on the data of 21 developed and 19 developing countries. This research allowed for establishing that the formation of capital structure in all markets can be described by the dynamic trade-off concept. Kokareva [29] in her research of the capital structure of companies from emerging financial markets came to the conclusion about the importance of the dynamic trade-off concept in the selection of the ratio of own and borrowed capital. It was found that traditional determinants of capital structure identified in the data of developed capital markets also has an impact on the target level of debt of companies in the BRIC countries and Eastern Europe. However, target financial leverage is also affected by factors reflecting the agent's motives, ownership structure, and corporate governance. The speed of adjustment to target debt depends on macroeconomic indicators (inflation rate, GDP growth rate) and determinants of the concepts of funding and tracking of the capital market. It should be noted that the problem of choosing sources for external financing is relevant for any economy. In the case of the transition economy, China should take into account that the mechanisms of corporate financing are at the stage of formation. The system of corporate institutions is very specific. It should also be borne in mind that the parameters of financing are influenced by the ideological preferences of the state. In this case, a special tool is needed to analyse the financing policy of Chinese companies.

The debt financing institutions in developing countries and countries with economies in transition are developing more rapidly than fund-raising mechanisms. However, the Chinese stock market has been in existence for more than two decades, and its importance is growing in the 
world of global corporate finance. In this regard, it is important to compare the logic of decision-making on financing from companies operating in the transitional economy of the BRIC countries and China, as although the stock market in each of these countries has been developing for approximately the same amount of time, the dynamics and characteristics remain notably different.

Thus, this paper aims to address a gap in the literature by empirically examining the relationship between the use of debt in the capital structure of companies in emerging markets and the relevant factors related to the capital structure.

The immediate goal of all development activities in this field is the identification of mechanisms for the choice of capital structure, the factors on which these mechanisms depend, and the impact of this choice on the value of the company. This is because an increase in cost reflects the welfare of the owners of the company, and therefore also indicates the status of progress in reaching the commercial targets of the managers working within it.

Attempts to explain the capital structure may be reduced to two approaches: the static (trade-off) approach and the dynamic approach. The first approach assumes that the firm should follow a certain policy with their capital as long as the marginal benefits of such actions are not reduced by the marginal costs (trade-off). This means that every company has a certain optimal capital structure which maximises its value.

\section{Review of Chinese Market}

Huang and Song [30] believe that in the case of Chinese companies the institutional environment is characterised by two factors. The first factor is a recognition that the Chinese economy is at a transitional stage. Being the world's second largest economy, it plays an important part in the global economic system. At the same time, the region lacks a modern financial system [31]; [32]. For example, the Chinese bond market is still developing, and treasury bills represent just 3\% of corporate bond issuance [33]. Secondly, the majority of Chinese-listed companies are state-owned enterprises (SOEs) [34]. Unlike developed countries, China does not have effective financial supervision mechanisms and bankruptcy constraints, while SOEs are subject to soft credit constraint. The government controls most of the SOEs' stocks, and even after the split share reform of 2005, it still plays a major role in determining listed firms' capital structure [35]. Chen et al. [31] state that this increases the chances of agency conflicts happening between managers and investors, as the former have limited rights to make decisions concerning capital structure. Managers who own only a small percentage of the company's shares are more focussed on personal benefits than on maximising investors' wealth and firm value.

Chen [32] claims that Chinese companies use retained earnings for financing purposes more often; however, more recent evidence indicates a trend towards equity financing. 282 companies were registered on the stock market in 2011, with US $\$ 45.3$ billion raised in new equity funds. It is significantly lower than the US\$76.3 billion raised in 2010, but it is still better than the year 2009 where only 99 newly listed companies raised US $\$ 29.6$ billion.

While there are many studies on capital structure determinants in China [36]; [37], none of them focus on foreign firms, whose presence may affect the overall situation. These articles offer an empirical analysis based on a large dataset covering more than 85 percent of China's total industrial output. The reason why there are no empirical studies of the impact of foreign companies on a firm's capital structure may be that there are no databases available. According to prior research on China, different financing decisions may depend on the type of company in question (public or private), which is why we investigate the impact of foreign presence on the capital structure of private, public and collectively owned firms separately.

\section{Determinants of Capital Structure of Chinese Companies}

A classic method of identifying the determinants of capital structure is based on the construction of linear regression. It is necessary to determine the number of potential determinants, the number of dependent variables, and the nature of their influence. A typical model, which is used to identify the determinants, can be formally written as a function of the debt burden from a number of factors:

$$
\begin{aligned}
& L=\eta+\eta 1 \text { Tax }+\eta 2 \text { Tangibility }+\eta 3 \text { Prof }+\eta 4 \text { Size }+ \\
& +\eta 5 \text { Risk }+\sum \eta j X j+v
\end{aligned}
$$

where Tax - a variable responsible for the tax benefits of debt capital; Tangibility reflects the structure of the company's assets; Prof is a variable that reflects the profitability of the total capital of the company; Size - the size of the company; Risk is a variable reflecting the risk of the company; - is not that other as a vector of other determinants; $\Sigma \eta_{j} X_{j-}$ the vector of other determinants.

After determining dependent variables, it is useful to take into account the regional peculiarities of the markets of Latin America, Central and Eastern Europe, Asia, and Africa. Country risk and geographical location play very important roles in our model's construction.

The set of the independent variables is usually represented in empirical research by the following: non-debt tax shield, savings on income tax, quality of assets, and the market to book coefficient. The first variable, savings on income tax (Tax), is caused by interest payments on the debt, because companies can raise leverage to increase tax benefits by using the spending interest to reduce taxable profits. The study of Cespedes, Gonzalez and Molina [38] about companies in Latin America confirmed the importance of the tax savings factor. However, not all emerging capital markets studies show the importance of the tax factor. Secondly, it takes into account the savings on income tax of non-debt origin (non-debt tax shield - NDT), since there are other potential sources of such savings. 
Thirdly, the quality of assets in the company can perform an important role in borrowing policy. Usually this parameter is linked to the proportion of long-term tangible assets (Tangibility) in total assets, as they can form the basis for collateral in case of borrowing. To reflect this, the proportion of fixed assets in total assets is commonly used: fixed assets/total assets or PPE/TA (property, plant and equipment to total assets). The higher the number of this coefficient, the more capacity the company has to increase borrowings. However, studies on emerging markets got contradictory results. For example, the expected direct impact discovered in the research on the data of Bahrain, Egypt, Qatar, Kuwait, UAE and Saudi Arabia [39]. But the opposite effect was revealed for Chinese companies [30]. Finally, in the test set of determinants, market-tobook, or the ratio of capitalisation shareholders ' equity to its book value is often included as a dependent variable. This ratio could reflect the growth opportunities of the company based on its strategic position and the prospect of development, because the numerator is based on the expectations of investors (market value of equity / book value of equity). But to account for the growth dynamics of a company, researchers use proxy variables of companies' growth rate.

The fact that immediately catches the eye in papers about emerging markets is the presence of variables responsible for agency conflicts in the company, which is extremely rare in models of companies in the U.S. To reflect the possible impact of the conflict there is a set of dummy variables responsible for the degree of information asymmetry in the models (agency dummies). For example, for Chinese companies, the shares which are not traded on the stock exchange (non-circulating share ratio) are used as an indicator, which is able to indirectly reflect the effect of agency costs on the overall cost [36].

To sum up information about emerging markets from different sources the following should be noted: the main determinants of capital structure remain important, although at times their effect is the opposite to that which is exhibited on Western European or American markets. However, some very interesting results accrue for Chinese companies, where obtained data do not agree with any of the above theories of capital structure. If the analysis of the determinants of the capital structure of companies from other emerging markets showed results similar to developed countries, for Chinese companies the dummy variables that are responsible for a qualitative shift in the estimation of parameters played an important distinguishing role.

Based on the variables discussed in our theoretical framework, we will propose hypotheses which are to be tested in order to address the objectives of this research. These hypotheses are intended to investigate firm-specific factors such as firm size, firm growth, tangibility of assets, depreciation to total assets, return on assets (ROA), and tax shield - each of which are significant determinants of the level of leverage in capital of Chinese companies. It is also assumed that the presence of the Chinese state in the management of the company has a significant impact. The hypotheses based on the literature review are: (1) return on assets (ROA) has a negative influence on leverage in emerging markets, as well as for Chinese companies, (2) firm size has a positive influence on same, (3) tangibility of assets has a positive influence, (4) tax shield has a positive influence, (5) growth has a positive influence, and (6) the presence of the state in the management of the company can ensure company sustainability.

\section{Methodology}

As was mentioned in the foregoing literature review, modern concepts of choice of capital structure includes the theory of compromise and the theory of financing order. A quantitative test of these theories is constructed using two models. The first model allows us to identify the determinants of capital structure to draw a conclusion about the logic of a decision on financing within the company on the basis of significance of multiple regression coefficients. The model is set out as follows:

$L_{i t}=\alpha+X_{i t} \beta+\varepsilon_{i t}$

where $L_{i t}$ - the financial leverage in the i-th company in the year $\mathrm{t}$; $X_{i t}$ - the matrix of the determinants of capital structure for the $\mathrm{i}$-th company in the year $\mathrm{t}$; $\alpha$ is a constant variable; $\beta$ - coefficient of the determinants; $\varepsilon_{i t}$ - matrix of vectors of random variables for i-th company in the year $t$.

The dependent variable $\mathrm{L}$ can be expressed as the ratio of debt to value of total assets of the company or to the cost of equity capital. In general, debt capital includes longterm debts. For the evaluation of $\mathrm{L}$ one can use both the book and the market values. For this research we will use book value, because the value is reflected in the balance sheet at the time of raising funds and fairly reflects the balance of sources of financing used by the company. The second model takes into account the specifics of the theoretical concepts of capital structure choice. As was mentioned above, the most popular theories nowadays are trade-off and the theory of financing order. We have chosen to focus on the latter theory, as it has been less studied. The theory of financing order implies that companies first use internal sources of financing, and then resort to external sources. It turns out that the size of the debt itself reflects the accumulated financial deficit, and the increment of the debt shows the finance deficit of the current period. Therefore, the second research model is presented as follows:

$$
\text { Debt }_{i t}=\alpha+\beta \text { Deficit }_{i t}+\varepsilon_{i t}
$$

Where $D e b t_{i t}$ - the increment of the debt of the i-th company in year t; Deficit ${ }_{i t}$ - the current financial deficit of the $\mathrm{i}$-th company in year $\mathrm{t}$; $\alpha$ is a constant variable; the $\beta$-coefficient of variable of current deficit; $\varepsilon_{i t}-$ a matrix of vectors of random variables for $i$-th company. If we look at the model, then we can assume that if the theory of the order of financing is correct, then the coeffi- 
cient $\beta$ is equal to 1 , and the coefficient $\alpha$ is zero, and the financial deficit is covered by the value of the debt. The financial deficit is defined as the difference between cash flow from operating activities and cash payments for the period produced by companies. Data for both parts of the equation are taken from the income statement:

Deficit $_{i t}=D P_{i t}+\mathrm{CapEx}_{i t}+\Delta \mathrm{WC}_{i t}+\mathrm{Ref}_{i t}-\mathrm{OperCF}_{i t}$,

where Deficit ${ }_{i t}$ - current financial deficit of the i-th company in year t; $D P_{i t}$ - dividends paid out of the $\mathrm{i}$-th company in year t; CapEx_it - capital costs of the $\mathrm{i}$ - th company in year $\mathrm{t} ; \Delta \mathrm{WC}_{i t}$ - increase in working capital of the i-th company in year t; Ref_it - portion of long-term debt payable in the current period of the i-th company in year $\mathrm{t}$; OperCF $\mathrm{O}_{i t}$ - operating cash flow of the i-th company in year $\mathrm{t}$.

As we can see, the resulting deficit variable takes both positive and negative values. It is believed that it is preferable to replace negative values with zero, on the assumption that early repayment of debt is uncharacteristic for firms and the negative value of the deficit has no logical justification.

The set of data that was used for this study contains observations for 195 non-financial companies in the five year period between 2012-2016. The sample contains companies from the following industries: heavy manufacturing, light manufacturing, agriculture, oil and gas equipment, oil and gas, and the metallurgical sectors. It should be noted that this sample includes companies adhering to the principles of IFRS or US GAAP. Initial data on companies were taken from the Thompson Reuters service database and in some cases is supplemented with data from officially published company reports. All data are presented (or translated at the official rate of the Central Bank of the Russian Federation) in terms of millions of US dollars. The final sample contains data on 57 China companies and 90 other companies. The ratio of total debt (TDR, total debt ratio) was used as a dependent variable, which is defined as the ratio of the total interest debt of the company to the total amount of its debt and the value of its share capital.

The independent variables are selected on the basis of studies on emerging markets outlined in the literature review of the paper. The description of the variables is presented in table 1, which shows that the participation of the state in the management of the company and the presence of foreign shareholders were taken as fictitious variables describing the qualitative characteristics for all countries. Based on existing studies on the selection of capital structure for companies in emerging markets, some assumptions were made to determine the concept of the choice of capital structure from the nature of the dependence of the variable described on the determinants (positive, negative or ambiguous, i.e. “-”).

It should also be noted that all linear regressions were tested to fulfill the conditions of the Gauss - Markov theorem. Fulfilling the conditions of this theorem means that the model is correctly specified, the vector matrix determinant $\mathrm{X}$ _it is not random, and the mathematical expectation of all the constituent elements of the random variable vector- $E\left(\varepsilon_{i t}\right)$ - is zero:

$$
E\left(\varepsilon_{i t}\right)=0
$$

In addition, the homoscedacity condition is fulfilled (the condition of equal variances- $\operatorname{Var}\left(\varepsilon_{\mathrm{it}}\right)$ - in the constituents in the $\mathrm{i}$-th equation):

$$
E\left(\varepsilon_{i t}^{2}\right)=\operatorname{Var}\left(\varepsilon_{i t}\right)=\sigma^{2}
$$

In all considered models of linear regression the condition of absence of autocorrelation is fulfilled:

$$
E\left(\varepsilon_{i t} * \varepsilon_{j t}\right)=\operatorname{covariance}\left(\varepsilon_{i t} ; \varepsilon_{j t}\right)=0
$$

\begin{tabular}{|c|c|c|c|}
\hline Indicator & Description & $\begin{array}{l}\text { The theory of } \\
\text { financing order }\end{array}$ & $\begin{array}{l}\text { The theory of } \\
\text { compromise }\end{array}$ \\
\hline Tangibility & Non-current assets to total assets ratio & Negative & Positive \\
\hline $\begin{array}{l}\text { ROA (Return } \\
\text { on Assets) }\end{array}$ & $\begin{array}{l}\text { Return on assets expressed as a ratio of net profit to total } \\
\text { assets of the company }\end{array}$ & Negative & Positive \\
\hline Growth & The ratio of capital to total assets of the company & Ambiguous & Negative \\
\hline
\end{tabular}

Table 1. Description of independent variables for analysis.

Tax
income before taxes

NDT «Non - tax shield, expressed as the ratio of depreciation to total assets

Ambiguous

Positive 


$\begin{array}{ll}\text { Indicator Description } & \begin{array}{l}\text { The theory of } \\ \text { financing order theory of }\end{array} \\ & \text { compromise }\end{array}$

Fictitious variable that reflects the presence of the state in

Gov the management of the company, and if the share of the state is equal to or more than $30 \%$, the value is 1 , if strictly less than 0

A fictitious variable that takes the value investors in the Foreign company's share capital is between $10 \%$ and $25 \%$, otherwise the value is 0

Source: [40]

Table 2. The results of assessing the determinants of capital structure of Chinese and another developing companies.

\begin{tabular}{|c|c|c|}
\hline & \multicolumn{2}{|c|}{ TDR } \\
\hline & Emerging markets & $\underline{\text { China }}$ \\
\hline Tangibility & $-0,1389$ & 0,2207 \\
\hline ROA (Returm on Assets) & $-0,2587$ & $-0,5998$ \\
\hline Growth & 0,1807 & $-0,0012$ \\
\hline $\operatorname{Tax}$ & 0,0030 & 0,0019 \\
\hline NDT & $-0,0411$ & 0,3420 \\
\hline Size & 0,0180 & 0,0543 \\
\hline Gov & 0,0924 & 0,0805 \\
\hline Foreign & 0,0094 & 0,0907 \\
\hline Const & 0,4065 & $-1,216$ \\
\hline Number of observations & 90 & 57 \\
\hline R-square & 0,5112 & 0,2349 \\
\hline F - statistics & 5,60 & 2,46 \\
\hline Probability $>$ Fobserved & $(0,000)$ & $(0,000)$ \\
\hline
\end{tabular}

Due to the fact that the data are analysed not only for individual companies, but also for five years, we will use the panel data method. Based on the methodology of previous studies, the data obtained can be viewed from the perspective of the pooled regression (Fisher's Test) by the least squares method (LCM). The results for China and other countries are presented in table 2 . The significance of variables was checked, with $\mathrm{F}$ - statistics evaluated at a $10 \%$ significance level.

\section{Results and Discussion}

The analysis of the data led to the following conclusions. First, there was a positive correlation between the share of non-current assets in total assets (Tangibility) and the financial leverage for Chinese companies. On the one hand, this dependence is quite understandable: non-current assets can be used as deposits when obtaining a long-term loan. On the other hand, in cases where agency costs are relevant, there is an asymmetry of information, which affects the low initial valuation of shares in the initial offering. As a rule, the availability of powerful and updated fixed assets, which occupy most of the non-current assets, can neutralise these negative effects. Thus, the two concepts of capital structure choice under consideration cannot be rejected.

It should be noted that the financial leverage of companies in developing countries has a negative dependence on the tangibility index. It may be connected with the low collateral value of long-term tangible assets, the presence of a large number of obsolete equipment, and limited service life. The question as to why the same situation is not observed in the China in this situation is quite logical: if we look at the results of the work of H. Li and L. Cui on Chinese companies in the period from 1994 to 2001 in the sectoral context, it can be seen that the metallurgical 
sector showed results similar to those obtained for Russian companies [37]. According to the results of previous research (e.g. [13]; [36]) the tangibility of assets asserts a positive influence on financial leverage. Firms investing in intangible assets in countries with good creditor protections have better accessibility to leverage as evidenced by Pandey [13], Haron [23].

It should be noted that the inverse relationship was not obtained for all sectors - the oil and gas sector was the exception. All BRIC companies in this sector have shown positive dependence of variable L on Tangibility. It is no secret that for example Russian companies engaged in the extraction of natural resources have a sufficiently large debt burden. Nevertheless, the high cost of oil and gas equipment, fixed assets, and support from the state (most oil and gas companies in the sample in two countries have direct links with the state, as proven by the importance of the fictitious variable Gov), allows them to count on additional long-term loans if necessary.

Secondly, the inverse relationship between leverage and ROA was obtained for all countries. Such a result confirms that we should apply the concept of financing order. Now, if we recognise certain institutional features of the Chinese financial system, we can find more convincing reasons than the risk of underfunding investment projects put forward by the theory of financing order. Probably, although Chinese banks issue long-term loans to listed companies, their credit opportunities are not unlimited (even though budget constraints appear soft). At the same time, the corporate bond market is not developed. Due to the imbalance in the legal framework for trading and issuing shares, the rights of individual investors, the players who occupy the most part in the market, are affected, and this makes the issue of shares less binding to the fulfillment of obligations under the contract than the issuance of bonds. At the same time, there is no "tax shield" effect in China. In conclusion, the issuance of shares in certain situations is preferable than the attraction of debt funds.

Thirdly, the growth rate of the company has proved to be a significant determinant for the financial leverage of Chinese companies, but it has shown to be insignificant in the sample of BRIC companies. This observation can be explained by the fact that managers of fast-growing companies expect cash inflow in the future and do not hurry with debt financing. However, it is hardly to say unequivocally about the applicability of the theory of compromise to Chinese or BRIC companies. After all, the fact is that the majority of companies in the sample are representatives of such sectors as electricity, metallurgy, and mining. Fixed assets of such kind of company are near about 70\% from total assets (Baosteel Group, Wuhan Iron \& Steel Group, Hebei Iron \& Steel Group, JSC “Evraz group”, JSC “Severstal”, JSC “NK Rosneft", with JSC "Gazprom” at a little more than 78\%) [41], and other intangible assets occupy at least $5-7 \%$. Narrowing opportunities for knowledge-based development hinders the growth prospects of companies.

Fourth, the indicator of the "tax shield" showed a low significance at the $10 \%$ level for all countries. If we pay attention to the nature of the impact of savings on income tax (not related to debt financing), we can reveal a positive relationship for BRIC companies, while Chinese companies showed the opposite result. If we look at the same indicator separately for each year, the situation remains the same for BRIC companies, and in China the sign of the coefficient in the determinant of NDT changes from positive to negative and vice versa. Most likely, the management annually corrects the financing policy, which is caused by the unstable situation in the market of metals, oil, jumps in the market of gold and coal, and the peculiarities of pricing in the electricity market.

In the coming years, we are likely to see higher debt ratios as a result of two trends: first, financial leverage is becoming more influenced by profitability, and second, profitability itself is on the decrease. This can affect Chinese companies' sustainable financial development in the future.

There is a significant positive association between firm size and financial leverage. Pandey [13] and Nivorozhkin [16] also came to the conclusion that company size has a positive impact on capital structure.

Under the conditions of China, the fictitious variable Gov turned out to be significant for the majority of companies in the oil and gas and metallurgical sectors in the sample. If we think about the institutional features of the financial system of China as soft budget constraints, underdevelopment of the corporate bond market, the underdeveloped legislative and regulatory framework for the balanced regulation of financial markets, and weak legally enforceable protection of creditors and shareholders, it becomes clear that major Chinese companies have the opportunity not on to take in debt and to answer for the loan in case of default, but also to collect large sums of money from the issues of shares. The relationship is also observed by previous empirical studies such as Chen [32], and Ding [1].

We can see that corporate leverage is restrained by profitability, and this influence has grown rapidly over the past few years. One of the reasons for that is a considerable decrease in lending rates after a large-scale stimulus program, which encouraged Chinese companies to borrow money instead of relying on retained earnings. This factor, along with lower profitability, has strengthened the association between capital structure and earnings.

In general, it can be noted that the results obtained for Chinese companies reflect the systemic features of the capital market in the country. The obtained differences in the results of the study between Chinese and BRIC companies reflect differences in the institutional structure of financing mechanisms in countries. The sample also did not show an unambiguous need to strictly follow to one of the classical concepts of capital structure choice, due to the multidirectional action of determinants. On the one hand, there is some evidence that Chinese companies put equity issuance above debt financing in the hierarchy. But, on the other hand, in absolute terms, lending, as was shown earlier in the paper, far exceeds equity financing. 


\section{Conclusion}

This study identified the determinants that are considered significant to developed markets. They also remain relevant in the selection of capital structure by companies in emerging markets, although the impact for some Central and Eastern European countries is the opposite of that for Western European or American markets. The results are particularly interesting for Chinese companies: the data obtained do not agree with either the theory of the financing order or the compromise theory. In addition to the multidirectional influence of the indicators themselves, fictitious variables responsible for the qualitative shift in assessing the parameters of Chinese companies played an important distinctive role in the studies reviewed. As was discovered later, the main reason for such results was the peculiarity of the institutional structure of the Chinese economy, systemic risks and problems that are unusual for other developing countries.

Most of the hypotheses put forward in this work have been confirmed by the results of the study. In China, lending dominates joint financing. This is due not only to the fact that historically the debt market is formed faster than the equity financing market. As outlined above, there are a number of factors that support this imbalance in the Chinese economy: a distorted system of primary placement, a segmented structure of the stock market, and a limited admission of foreign investors to the stock financing market.

The findings on the development of mechanisms of direct corporate financing in China allowed for interpreting the data in the empirical analysis of the largest companies in BRIC and China. The analysis of the functioning of the capital market in China made it possible to assess the dependence of the variable financial leverage on the determinants of the capital structure more accurately.

The quantitative study confirmed the hypothesis that in some cases Chinese companies put the issue of shares above debt financing. On the one hand, the result contradicts the general situation of predominance of debt financing over equity financing. On the other hand, some companies are forced to resort to the issue of shares in view of the existing significant debt burden. Moreover, the underdeveloped corporate bond market also hinders the free issuance of debt instruments by large Chinese industrial companies. It turns out that at a certain stage, with the decrease in credit opportunities of large banks in China, there is an increase in the issuance of shares as more attractive instruments than debt financing.

The experience gained in the process of writing this work is ambiguous: on the one hand, it was possible to understand the basics of the stock market as a whole. On the other hand, the differences in the functioning of equity financing mechanisms in China were revealed, and the influence of the determinants of the capital structure for Chinese and BRIC companies was compared, which imparted certain knowledge necessary to understand the motives of Chinese investors.

\section{References}

1. Ding X. Asymmetric Information in Emerging Markets: Lessons from China. 2011.

2. Delcoure N. The determinants of capital structure in transitional economies. International Review of Economics \& Finance. 2007; 16 (30): 400-4152007

3. Rajagopal S. The probability of capital structure theory: Do traditional models fit in an emerging economy? International Journal of Law and Management.2011; 57(1):53-83. DOI: 10.1108/ IJLMA-01-2013-0004

4. Manos R., Murinde V., Green C. J. Leverage and business groups: Evidence from Indian firms. Journal of Economics and Business. 2007; 59(5): 443-465.

5. Modigliani, F. and Miller, M. The cost of capital, corporation financing and the theory of investment. American Economic Review. 1958; 48(3):261-297.

6. Moyer, R.C. McGuigan, J. R. and Kretlow W. Contemporary Financial Management, 2006. 10th ed., South-Western Pub, Cincinnati, USA.

7. Gitman, L. Principles of Managerial Finance. 2007. 10th ed., Addison Wesley, New York, USA.

8. Scott, D. M. Petty, J. and Keown, A. Basic Financial Management. 2000. Prentice Hall, 8th ed., New Jersey, USA.

9. Simerly, R. and Li, M. Environmental dynamism, capital structure and performance: a theoretical integration and an empirical test. Strategic Management Journal. 2000; (21):31-49.

10. Booth, L. Aivazian, V. Demirguc-Kunt, A. and Maksimovich, V. Capital structures in developing countries. The Journal of Finance. 2001; (56):87-130

11. Bhaduri, S. Determinants of capital structure choice: a study of the Indian sector. Applied Financial Economics. 2002; (12): 655-665.

12. Kumar, S, Colombage, S, Rao, P. Research on capital structure determinants: a review and future directions. International Journal of Managerial Finance.2017; 13 (2):106-132

13. Pandey, I. Financial management. 1999. 8th ed., Sangam Books Ltd, New Delhi, India.

14. Abor, J. Determinants of Capital Structure of Ghanaian Firms. African Economic Research Consortium Paper. 2008; (176): 1-29.

15. Mitton, T. Why Have Debt Ratios Increased for Firms in Emerging Markets? European Financial Management.2008; 14(1):127-151.

16. Nivorozhkin, E. Capital Structures in Emerging Stock Markets: The case of Hungary. The Developing Economies. 2002; 40(2):166-87. 
17. Ivashkovskaya, I. and Solntseva, M. Capital structure choice in BRIC: do Russian, Brazilian and Chinese firms follow pecking order or trade-off logic of financing?", GBATA 11th International Conference, Prague, Czech Republic, 2009, pp. 572-579.

18. Ivashkovskaya, I. and Makarov, P. Are the classical concept of structure selection capital in emerging markets? Empirical analysiscompanies in Eastern and Central Europe". Corporate Finance.2010; 3(15): 47-62.

19. Tong, G. and Green, C.J. Pecking order or trade-off hypothesis? Evidence on the capital structure of Chinese companies. Applied Economics. 2005; 37(19): 2179-2189.

20. Alani, M.K \& Alamri, M.S The determinants of capital structure: an empirical study of Omani listed industrial companies. Business: Theory and Practice.2015; 16(2), 159-167.

21. Acaravci, S.K. The determinants of capital structure: evidence from the Turkish manufacturing sector. International Journal of Economics and Financial Issues. 2015; 5(1): 158-171

22. Rahim, N., \& Saad, N. Sustainable Growth of Public Listed Companies (PLC) Using Capital Structure Choices and Firm Performance in an Asean Market. 2014. Proceeding of the Global Summit on Education GSE, 4-5.

23. Haron, R. Key factors influencing target capital structure of property firms in Malaysia. Asian Social Science.2014; 10 (3): 62-69.

24. Fama, E., and K.R. French, Testing trade-off and pecking order predictions about dividends and debt. Review of Financial Studies. 2002; 15:1-33.

25. Kemsley D., Nissim D. Valuation of the debt tax shield. The Journal of finance. 2002; 57(5): 2045-2073.

26. Baker, M., and J. Wurgler. Market timing and capital structure. Journal of Finance. 2002; (57):1-32. DOI: $10.2139 /$ ssrn. 267327

27. Vo, X.V. Determinants of capital structure in emerging markets: Evidence from Vietnam. Research in International Business and Finance. 2017; (40): 105113

28. Clark, B. Francis, B. and Hasan, I. Do firms adjust toward target capital structures? Some international evidence". Working paper (http://ssrn.com/ abstract=1286383). 2009

29. Kokoreva M. Choice of the capital structure of the companies in the BRIC countries and Eastern Europe: an empirical analysis. Corporate Finance.2012; (6): 58-70.
30. Huang, G. and Song, F. The Determinants of Capital Structure: Evidence from China". China Economic Review. 2006; (17): 23.

31. Chen, J. Jiang, C. and Lin, Y. What determine firms' capital structure in China?" Managerial Finance. 2014; 40(10): 1024-1039.

32. Chen, J. Determinants of capital structure of Chineselisted companies". Journal of Business Research. 2004; 57(12): 1341-1351.

33. Zhang, T. The problems and causes of capital structure within Chinese listed firms". Journal of Yunnan University.2008; 3(1): 13-16.

34. Sun, Q. and Tong, W. H. China share issue privatization: the extent of its success" Journal of Financial Economics. 2003; 70(2): 183-222.

35. Liu, Q., Tian, G., and Wang, X. The effect of ownership structure on leverage decision: new 65 evidence from Chinese listed firms". Journal of the Asia Pacific Economy. 2011; 16(2): 254-276.

36. Li, K. Yue, H. and Zhao, L. Ownership, institutions, and capital structure: Evidence from China”. Journal of Comparative Economics. 2009; (37): 482.

37. Li H., Cui L. Empirical Study of Capital Structure on Agency Costs in Chinese Listed Firms. Nature and Science. 2003; 1(1): 46.

38. Cespedes, J. Gonzalez, and M. Molina, C. Ownership and capital structure in Latin America”. Journal of Business Research. 2010; (53): 250.

39. De Jong, A. Kabir, R. and Nguyen, T. Capital structure around the world: The roles of firm- and country-specific determinants". Erasmus Research Institute of Management. 2007; (53): 30.

40. Chen K., Wei J. Disclosure, Corporate Governance, and the Cost of Equity Capital: Evidence from Asia's Emerging Markets. 2003. Hong Kong: Hong Kong University,p.170.

41. "Emerging Markets: Group Statistics", NationMaster. Retrieved from http://www.nationmaster.com/ country-info/groups/Emerging-markets 